\title{
グラス・ファイバ・ダクト直管部の気流による発生騒音について ON GENERATED NOISE BY AIR FLOW AT STRAIGHT GLASS FIBER DUCTS
}

\author{
板本守正*, 塩川博義** \\ Morimasa ITAMOTO and Hiroyoshi SHIOKAWA
}

\begin{abstract}
For evaluating generated noise by air flow at straight glass fiber ducts, twelve kinds of straight ducts are studied. Pressure drop, sound attenuation and sound insulation characteristics of side wall of straight ducts are described.

Experimental and calculated method to evaluate generated noise by air flow at straight glass fiber ducts are discussed.
\end{abstract}

Keywords : glass fiber duct, generated noise, sound attenuation グラス・ファイバ・ダクト, 発生騷音, 音響減衰

\section{1. 緒 言}

前報では，グラス・ブァイバ・ダクト系を構成する各 種エレメントの気流および音響特性の一部を報告し だ!。音響特性では，音響減衰および直管部側壁の遮音 特性を明らかにしたが，灭流による発生音については都 合により測定できなかった。

一般にグラス・ファイバ・ダクトに限らず，気流によ る発生音は, 曲管部, 分岐部, 断面変化部などでは, 比 較的容易に測定できるが，直管部においては，発生音が 非常に小さく測定しにくい。そのため，ダクト系直管部 の発生音は，ダクト系の消音設計上実務的に無視する場 合が多いが，ダクト系全体では直管部の占める割合が大 きく無視できない場合もあり，無視すれば，危険側の設 計となることもある。このことから,グラス・ファイバ． ダクト直管部に関しても気流による発生音について設計 データが必要である。

ダクト直管部に送風した場合、気流による音の発生と 音響减衰との 2 つの作用が同時に行われる。ゆえに，前 者のみのデー夕を測定するのは不可能であり，測定デー 夕から両者を理論的に分離しなければならない。

音響減衰を考慮した単位長さ当たりで発生する騒音と して直管部発生音を算出する方法”があるが，音響減衰 が一般の鉄板ダクト直管部と大きく異なるグラス・ファ イバ・ダクトにこの算出法が適用できるかどうか明らか でない。
そこで，今回新たに 12 種のグラス・ファイバ・ダク 卜直管部を測定する機会を得たので，気流による発生音 について実験を行い，その実験データを踏まえながらグ ラス・ファイバ・ダクト直管部発生音の算出法を検討す る。

本報告では，新たなグラス・ファイバ・ダクト直管部 の気流特性, 音響減衰および側壁の遮音特性を設計デー タとして明らかにし，さらに気流による発生音の実験方 法およびその算出法を確立し，グラス・ファイバ・ダク 卜直管部の気流による発生音を明らかにする。

\section{2. 供試体の種類}

供試体を図一1 に示す。供試体は円形断面ダクト直管 部 7 種，正方形および長方形断面（以後，まとめて長方 形断面とする) ダクト直管部 5 種，計 12 種である。前

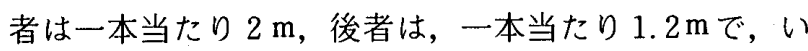
ずれも,それ以上の長さのダクト直管部が必要なときは, アルミテープでダクトを数本接続することができる。ま た，長さに合わせて容易に切断することもできる。供試 体は，いずれもダクト断面寸法で表す。

ダクト側壁を構成するグラス・ファイバは，厚さ 25 $\mathrm{mm}$, 密度 $64 \mathrm{~kg} / \mathrm{m}^{3}$, 単位重量 $1.6 \mathrm{~kg} / \mathrm{m}^{2}$, 許容応力 $5.5 \mathrm{~kg} / \mathrm{cm}^{2}$ で, 内表面をグラファイト・ペイントで処 理し, 外表面はグラス・ヤーンおよびアルミ箔で補強し てある。

\footnotetext{
本論文は日本建築学会および日本音管学会において発表した文献 3）および4）の内容を再検討し，まとめ直したものである。

*日本大学生産工学部建築工学科 教授. 工博 Prof., Dept. of Architectural Engineering, College of Industrial Technology, Nihon Univ., Dr. Eng.

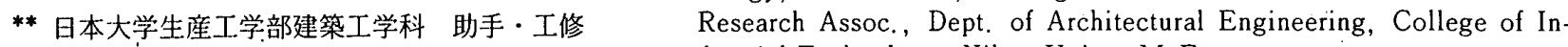
dustrial. Technology, Nihon Univ., M. Eng.
} 


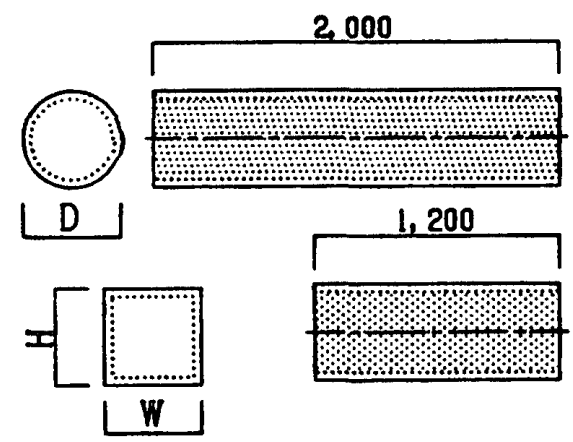

\begin{tabular}{c|c}
\hline Testunit & $\begin{array}{l}\text { Duct diameter(mint) } \\
\text { or mension WXH(mm) } \\
\text { dimens }\end{array}$ \\
\hline $150 \phi$ & 150 \\
\hline $200 \phi$ & 200 \\
\hline $250 \phi$ & 250 \\
\hline $300 \phi$ & 300 \\
\hline $400 \phi$ & 400 \\
\hline $500 \phi$ & 500 \\
\hline $600 \phi$ & 600 \\
\hline $200 \times 400$ & $200 \times 400$ \\
\hline $250 \times 450$ & $250 \times 450$ \\
\hline $400 \times 400$ & $400 \times 400$ \\
\hline $400 \times 500$ & $400 \times 500$ \\
\hline $400 \times 600$ & $400 \times 600$ \\
\hline
\end{tabular}

図一1 供武体の種類

また，各実験時におけるグラス・ファイバ・ダクトお よび鉄板ダクトの取り付け方法は, 現場での施工方法と 同様に行っている。

\section{3. 供試体の諸特性}

今回の供試体について，前報”で示した実験方法で求 めた気流特性，音響减衰および遮音特性を以下に示す。

\section{1 気流特性}

摩擦抵抗係数入を整理した結果を表一 1 に示す。円形 および長方形断面いずれも 0.024 前後を示す。

\section{2 音響減衰}

円形および長方形断面ダクト直管部を鉄板ダクトと接 続したとき，鉄板ダクトと接続してから $1 \mathrm{~m}$ 以降の音響 減衰の傾きから求めた単位長さ $(1 \mathrm{~m})$ 当たりの音響诚 衰を図一 2 および 3 に示す。円形断面ダクトは, 断面の 直径が大きくなるにつれて，減衰量は小さくなる。長方 形断面ダクトも断面寸法が大きくなるにつれて诚衰量は 小さくなるが, $200 \times 400$ の $2 \mathrm{kHz}$ 帯域を除けば, 全体 的に大きな差はない。

また, 鉄板ダクト直後 $1 \mathrm{~m}$ までの円形および長方形断 面ダクトの音響减衰を図一 4 および 5 に示す。上記で示
表一1 摩擦抵抗係数 $\bar{\lambda}$

\begin{tabular}{c|c}
\hline Testunit & $\begin{array}{l}\text { Friction } \\
\text { coefficients } \bar{t}\end{array}$ \\
\hline $150 \phi$ & 0.023 \\
\hline $200 \phi$ & 0.027 \\
\hline $250 \phi$ & 0.022 \\
\hline $300 \phi$ & 0.028 \\
\hline 4004 & 0.025 \\
\hline $500 \phi$ & 0.020 \\
\hline $600 \phi$ & 0.028 \\
\hline $200 \times 400$ & 0.025 \\
\hline $250 \times 450$ & 0.024 \\
\hline $400 \times 400$ & 0.026 \\
\hline $400 \times 500$ & 0.020 \\
\hline $400 \times 600$ & 0.024 \\
\hline
\end{tabular}

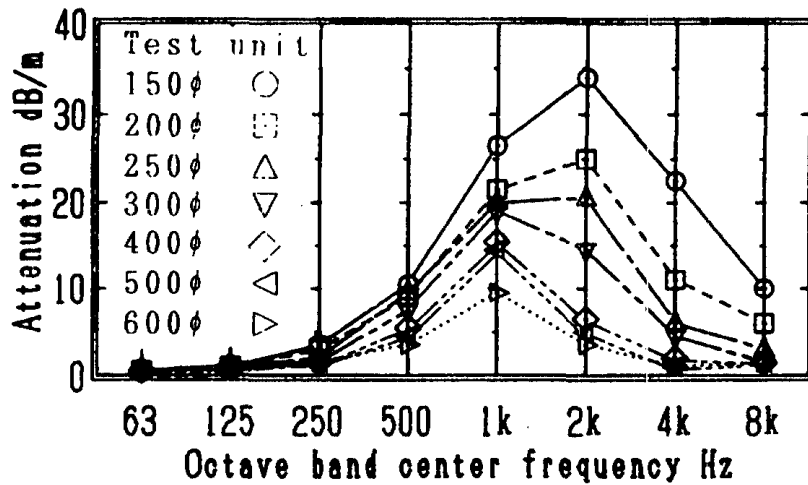

図一2 単位長さ $(1 \mathrm{~m})$ 当たりの音響减衰（円形断面ダクト）

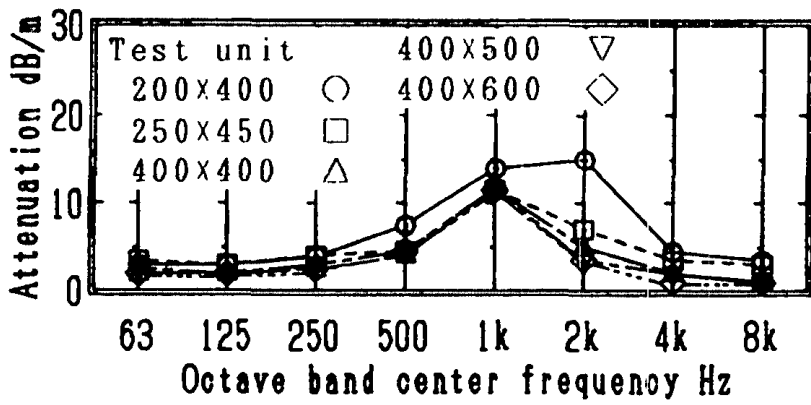

図一3 単位長さ $(1 \mathrm{~m})$ 当たりの音響减衰（長方形断面ダクト）

した音響減衰より全体的に大きいが，傾向としては，上 記と同様に断面寸法が大きくなるに従って減衰量は小さ くなる。

3.3 ダクト側壁の遮音特性

鉄板ダクトと接続したとき，鉄板ダクトからグラス。

ファイバ・ダクトへの入射音パワーレベルと:鉄板ダクト と接続されてから $1 \mathrm{~m}$ 以内のダクト側壁からの透過パ ワーレベルとの差を図一6 および 7 に示す。

円形断面ダクトは，500, $1 \mathrm{k}$ あるいは $2 \mathrm{kHz}$ 帯域まで 


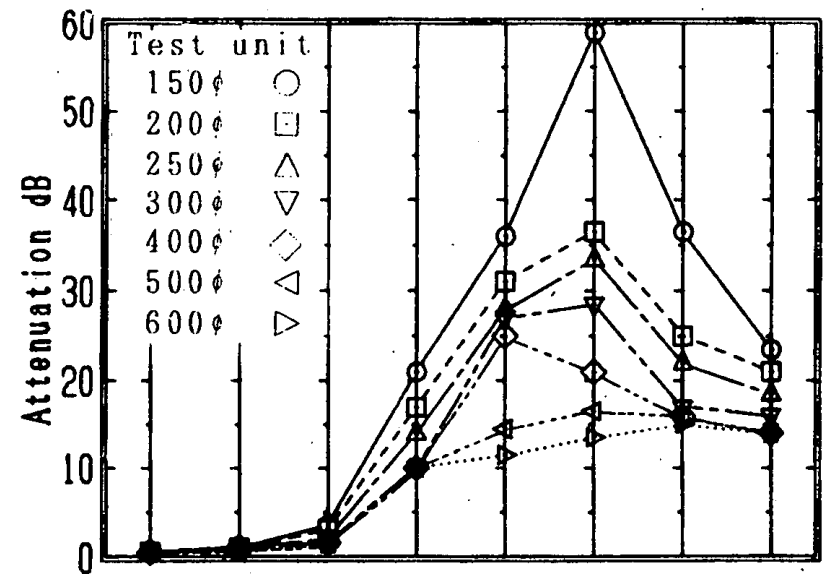

$63 \quad 125 \quad 250 \quad 500 \quad$ ik $2 k \quad 4 k \quad 8 k$ Octare band center frequenoy $\mathrm{Hz}$

図一4 鉄板ダクトとの境界部から $1 \mathrm{~m}$ の音響诚衰（円形断面ダ クト)

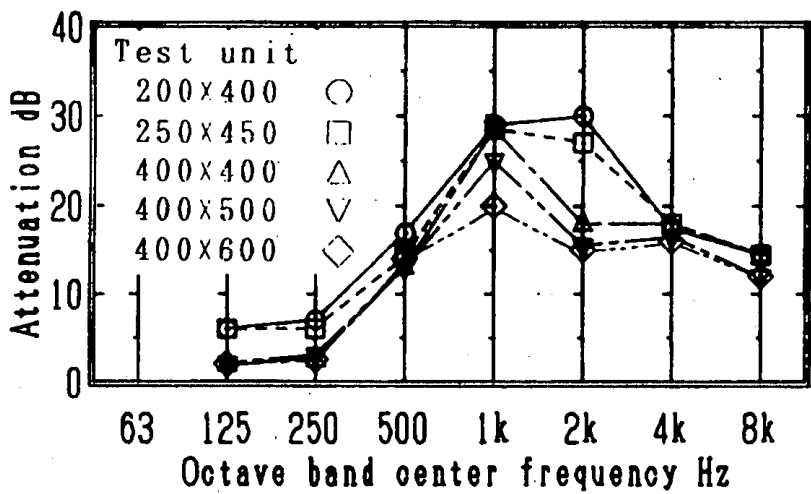

図一5 鉄板ダクトとの境界部から $1 \mathrm{~m}$ の音響減衰（長方形断面 ダクト)

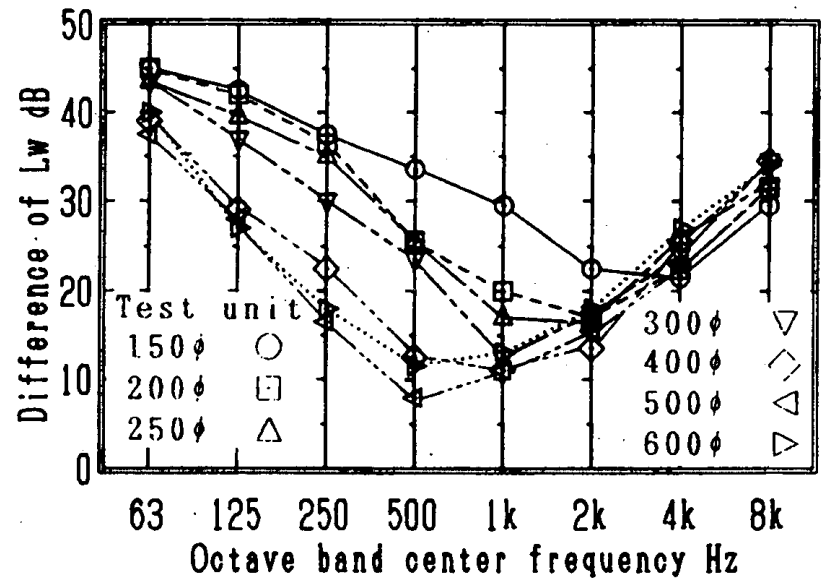

図一6 ダクト内から外へ透過する場合の遮音特性（円形断面ダ クト)

周波数が高くなるにつれてパワーレベル差は堿少し，そ れより周波数が高くなると増大する。長方形断面ダクト は，いずれも $1 \mathrm{kHz}$ 帯域までパワーレベル差が断面に よらずほぼ一定で，それより周波数が高くなるにつれて 增大する。

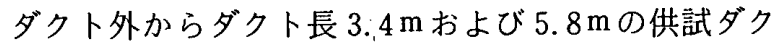

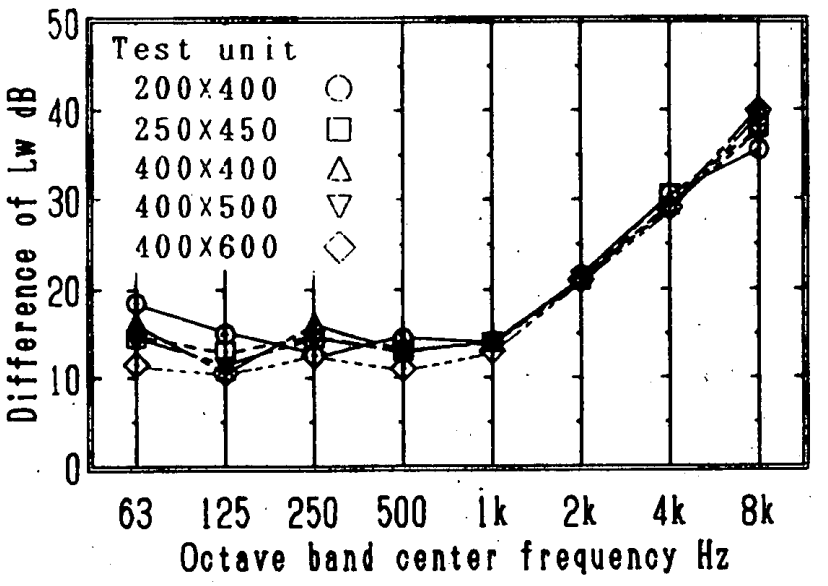

図一7 ダクト内から外へ透過する場合の遮音特性（長方形断面 ダクト)

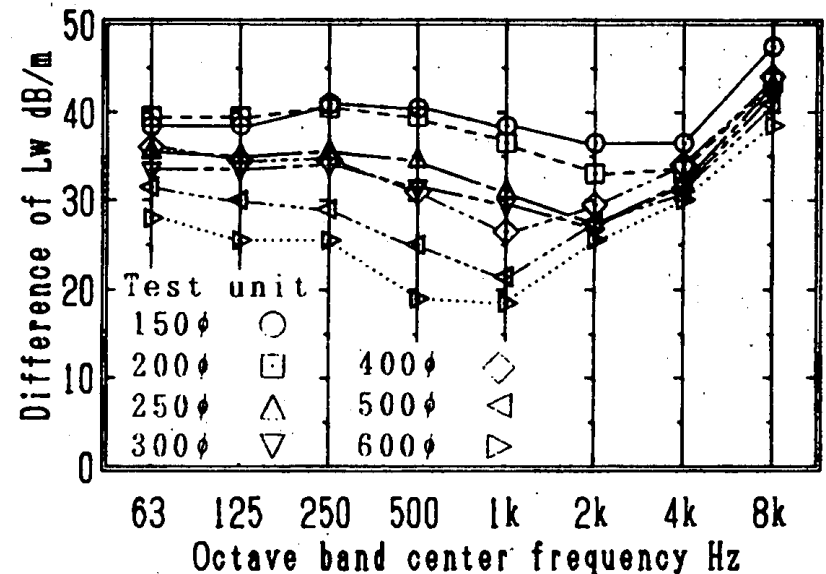

図一8 ダクト外から内へ透過する場合の遮音特性（円形断面ダ クト)

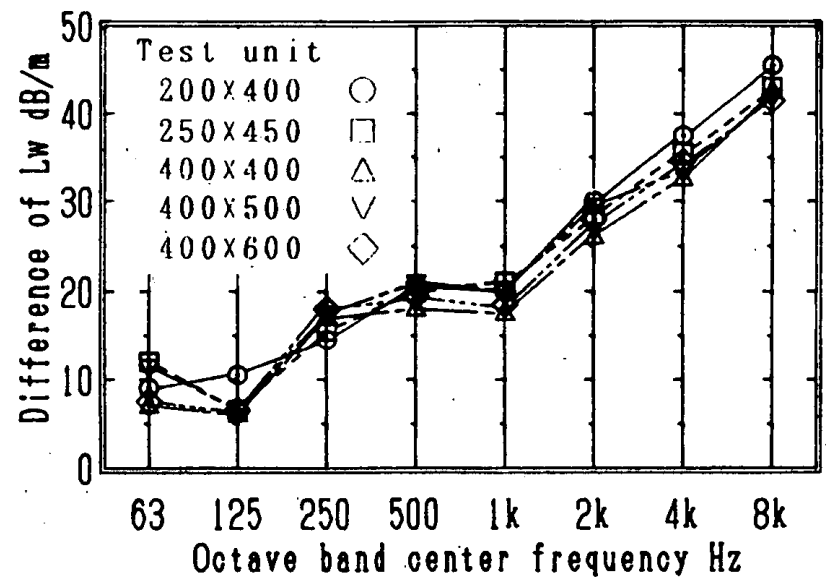

図一9 ダクト外から内へ透過する場合の遮音特性（長方形断面 ダクト)

ト側壁への入射パワーレベルとダクト内パワーレベルと の差から単位長さ $(1 \mathrm{~m})$ 当たりのパワーレベル差を求 めたものを図一8および 9 に示す。

円形断面ダクトのパワーレベル差は，1あるいは 2 $\mathrm{kHz}$ 帯域に最小值があり，8 kHz 帯域を除けば，ほぼ一 様な周波数特性を示す。長方形断面ダクトは, 一部を除 
き周波数が高くなるにつれてパワーレベル差も増大す る。

\section{4. 気流による発生騒音}

4.1 直管部発生音の算出法

音響減衰を考虑した単位長さ当たりで発生する音とし
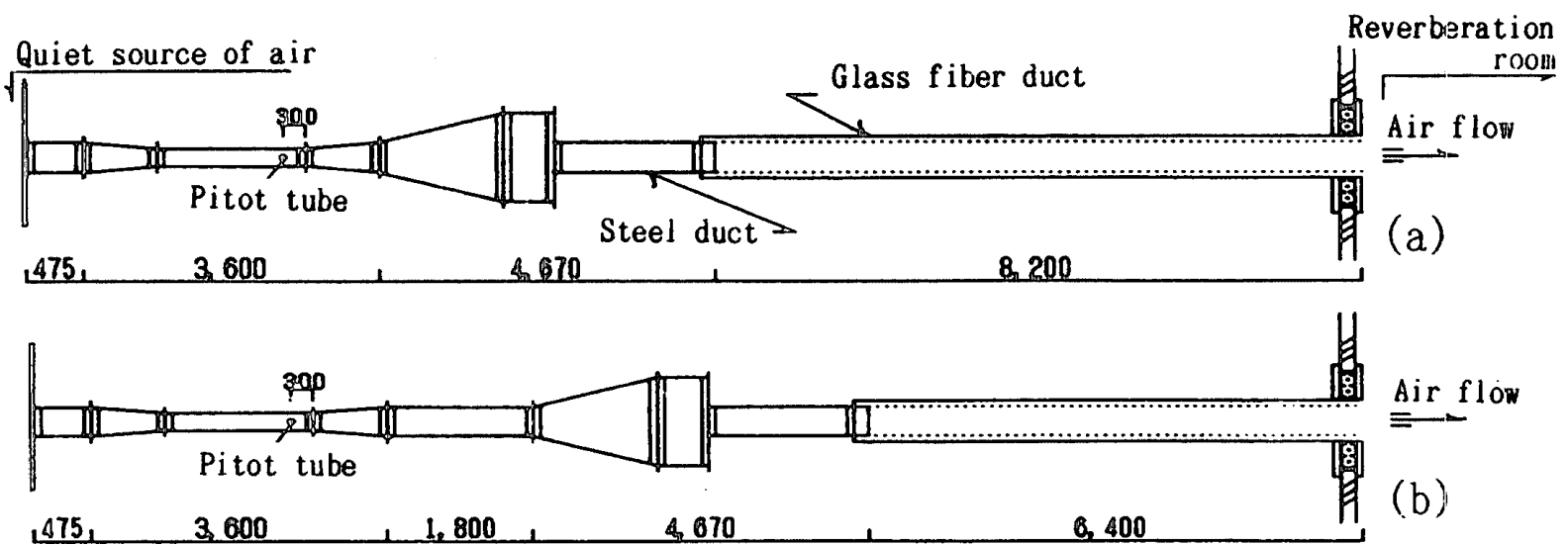

Air flow

(b)
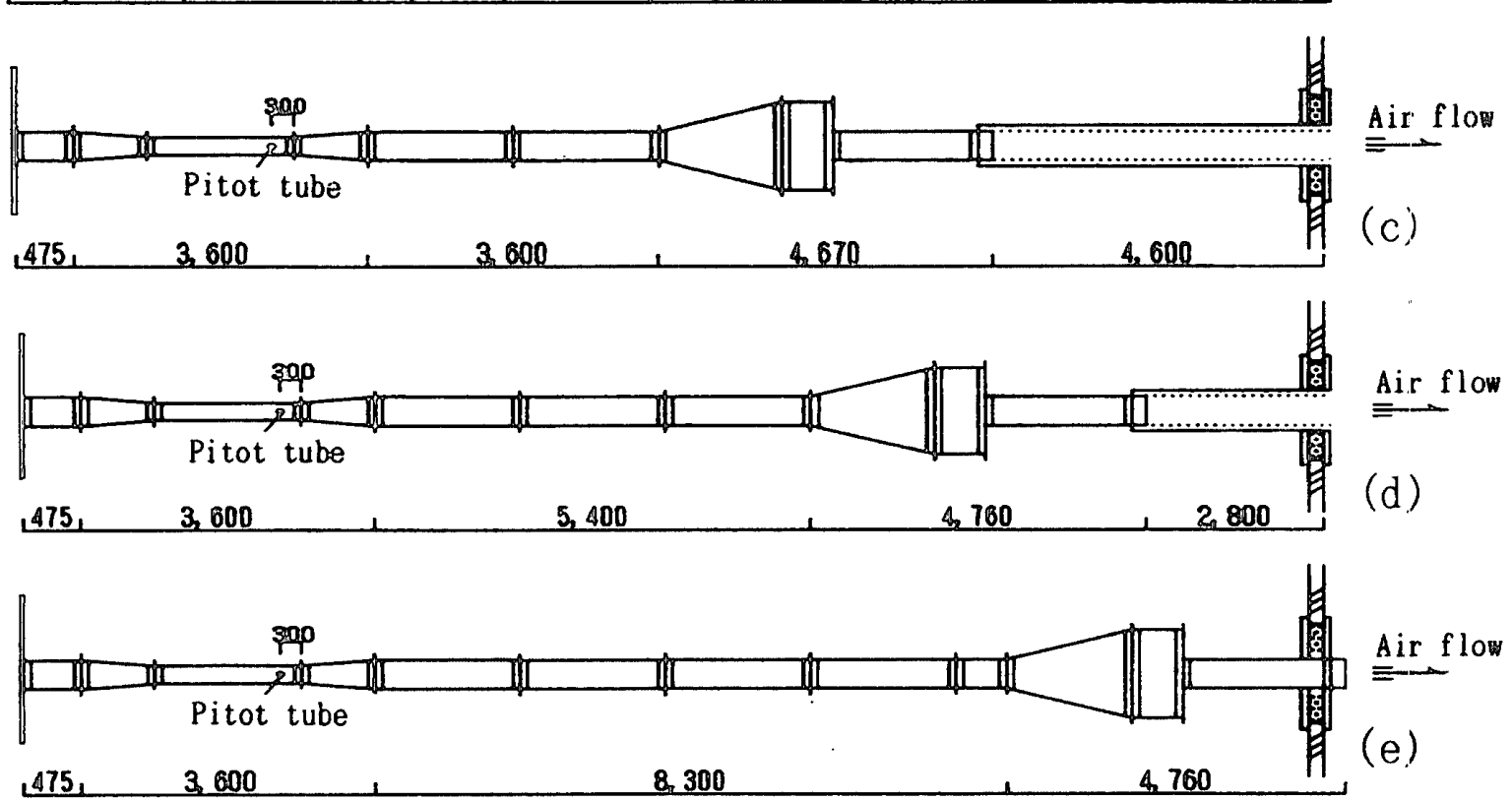

図一10 発生音の実験装膡

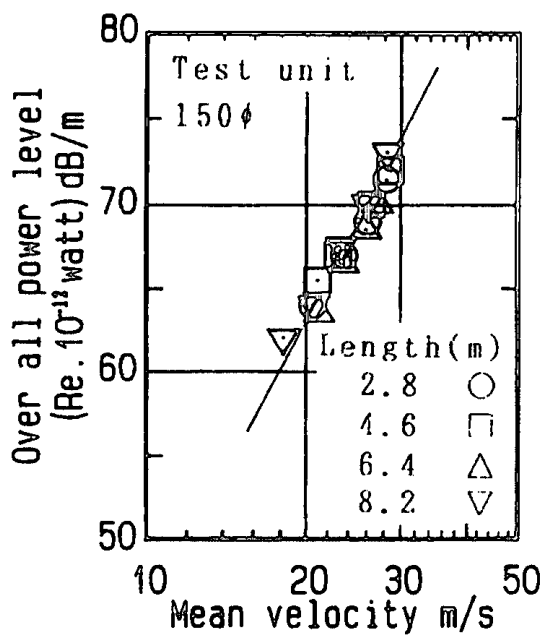

図一11 単位長さ $(1 \mathrm{~m})$ 当たりの発生音 $(150 \phi)$
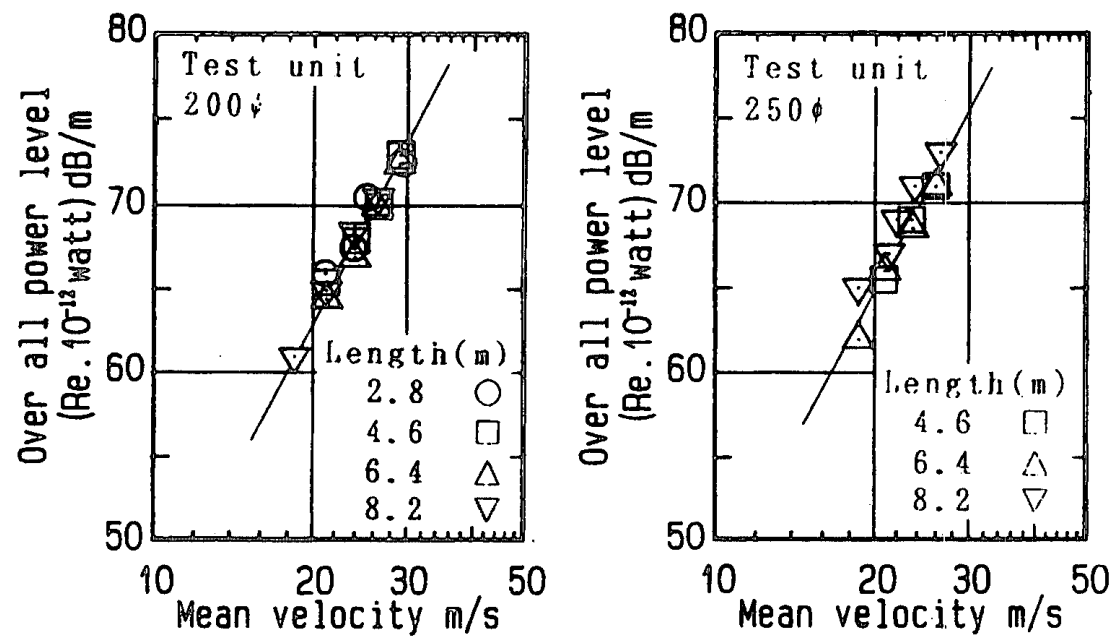
$(200 \phi)$
図一13 単位長さ $(1 \mathrm{~m})$ 当たりの発生音 $(250 \phi)$ 
法が適用できるかよ゙うか明らかでない。

そこで，すべての供試体について 4 段階の長さを設定 して $L w_{m}$ の测定を行い, 前述の単位長さ $(1 \mathrm{~m})$ 当た りの音響減衰を用いて,それぞれの直管部発生音を求め, この算出法がグラス・ファイバ・ダクト直管部発生音を 算出可能かどうか検討する。

$$
L w_{m}=L w_{1}+10 \log _{10}\left\{\left(1-e^{-k l}\right) / k\right\} \cdots
$$
ただし，

$L w_{m}:$ 任意の長さのダクト端におけるパワーレベル [dB]

$L w_{1}$ ：単位長さ当たりの発生音パワーレベル $[\mathrm{dB} / \mathrm{m}]$

$k$ : 単位長さ当たりの減衰係数 $(k=0.23 R / x)$

$R$ : 長さ $x \mathrm{~m}$ に対する減衰量 $[\mathrm{dB}]$

$l: タ ゙ ク ト の$ 長さ $[\mathrm{m}]$

\section{2 実験装置および方法}

実験装置を図一10に示す。無音送排風装置より各ダ クト系を通して給排気口を有する残響室に無音送風す る。これより，各ダクト系開口端から放射された気流に
よるダクト系の発生音を残響室法により測定してダクト 開口端パワーレベルを求める。また，ダクト系 $(\mathrm{e})$ の パワーレベルをダクト系 $(\mathrm{a})$ ～(d) における供試体上 流側ダクトの発生音とし，3.2で示した音響堿衰を用い てそれぞれ上流側ダクトの発生音がダクト開口端まで減 衰したものを求める。それらをダクト系 $(\mathrm{a})$ （d) の 開口端パワーレベルからエネルギ一的に減じて供試体ダ クト端におけるパワーレベル $L w_{m}$ をそれぞれ求める。

\section{3 実験結果および考察}

実験から求めた供試体ダクト端におけるパワーレベル $L w_{m}$ および 3.2 で示した単位長さ当たりの音響減衰を 用いて, 式（1）より求めたグラス・ファイバ・ダクト 直管部発生音のオーバーオール・パワーレベルとダクト 内平均流速との関係を図一11〜22 に示す。ただし，測 定はすべて各断面寸法につき 4 段階の長さについて行っ たが，一部長さによっては測定不可能なものがある。

いずれの供試体も直管部発生音オーバーオール・パ ワーレベルは平均流速のほぼ 6 乗に比例する。また, 長

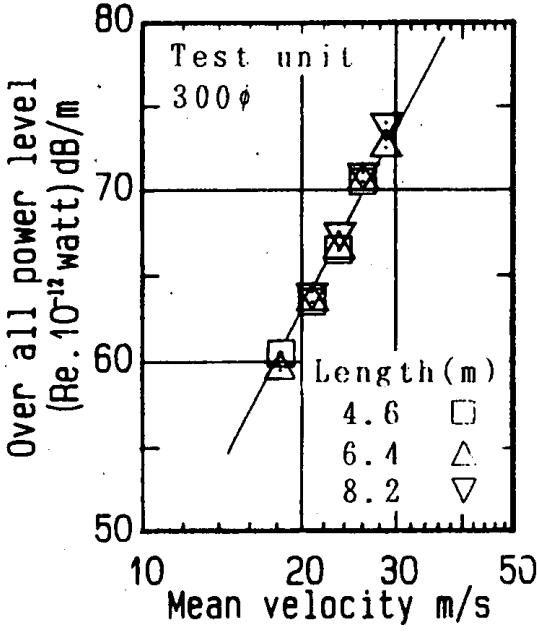

図一14 単位長さ $(1 \mathrm{~m})$ 当たりの発生音 $(300 \phi)$

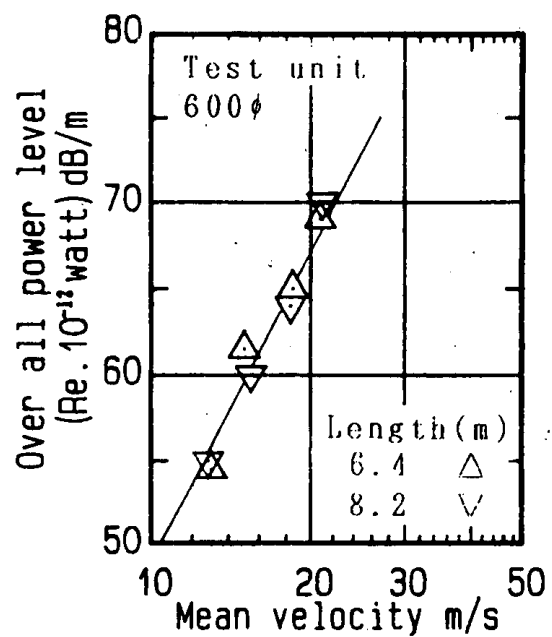

図一17 単位長さ $(1 \mathrm{~m})$ 当たりの発生音 $(600 \phi)$

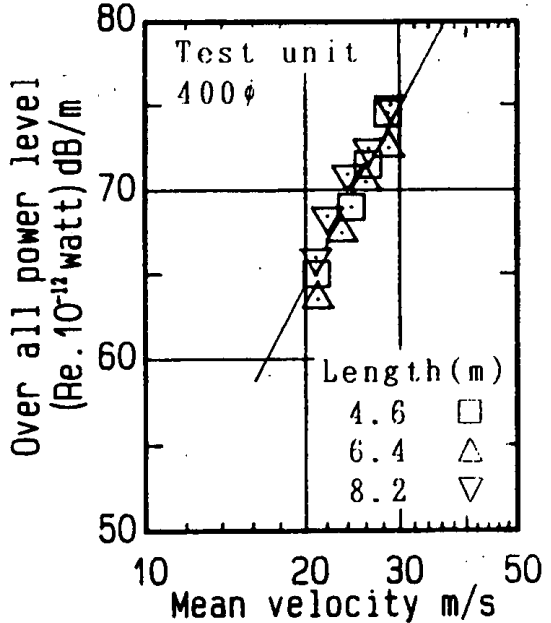

図一15 単位長さ $(1 \mathrm{~m})$ 当たりの発生音 $(400 \phi)$

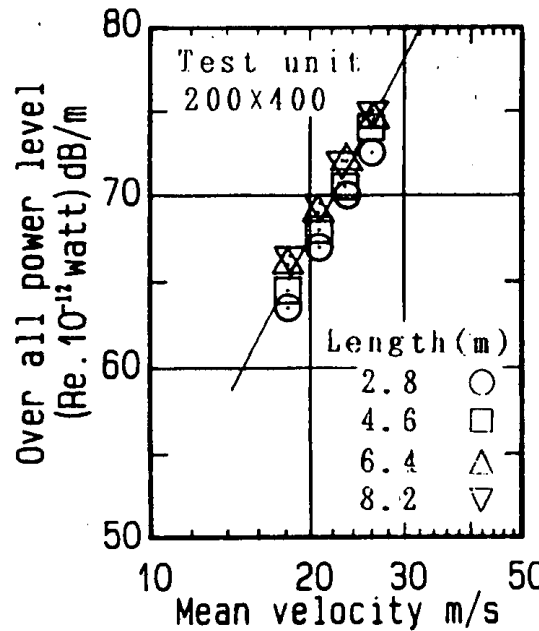

図一18 単位長さ $(1 \mathrm{~m})$ 当たりの発生音 $(200 \times 400)$

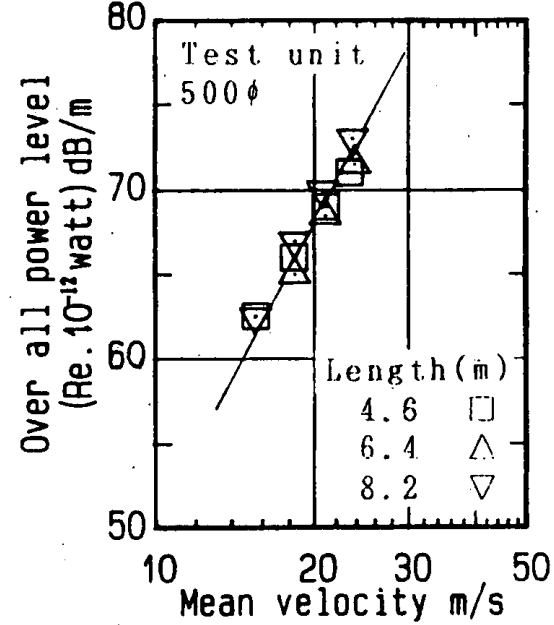

图一16 単位長さ $(1 \mathrm{~m})$ 当たりの発生音 $(500 \phi)$

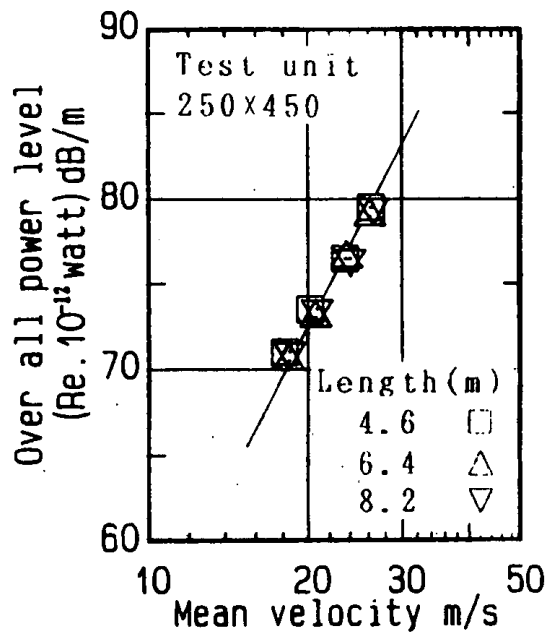

图一19 単位長さ $(1 \mathrm{~m})$ 当たりの発生音 $(250 \times 450)$ 


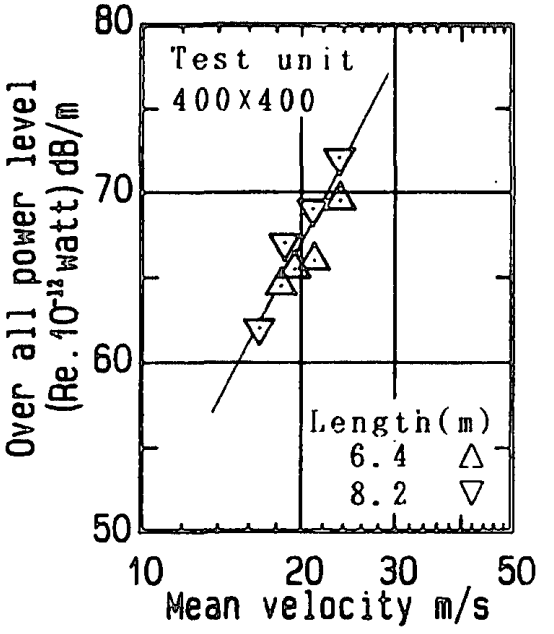

図一20 単位長さ $(1 \mathrm{~m})$ 当たりの発生音 $(400 \times 400)$

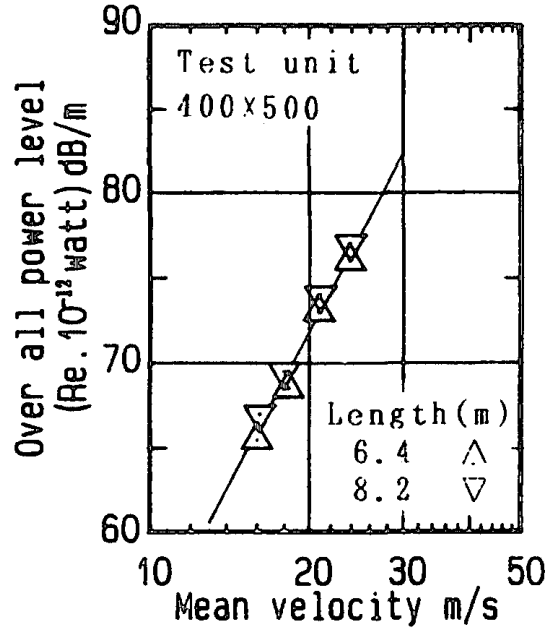

图一21 単位長さ $(1 \mathrm{~m})$ 当たりの発生音 $(400 \times 500)$

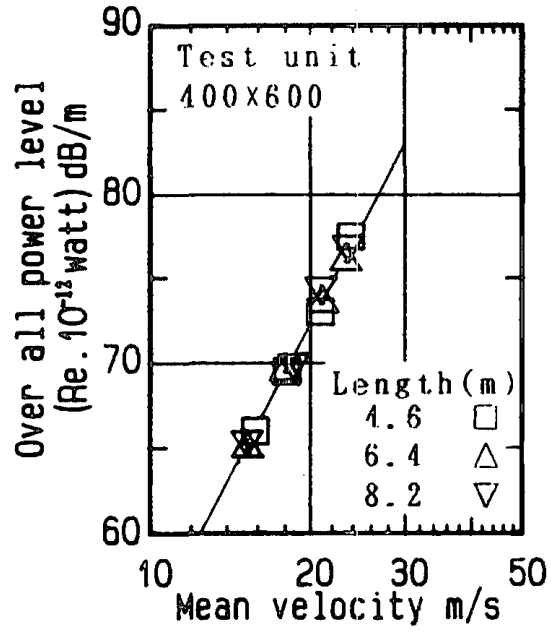

図一22 単位長さ $(1 \mathrm{~m})$ 当たりの発生音 $(400 \times 600)$

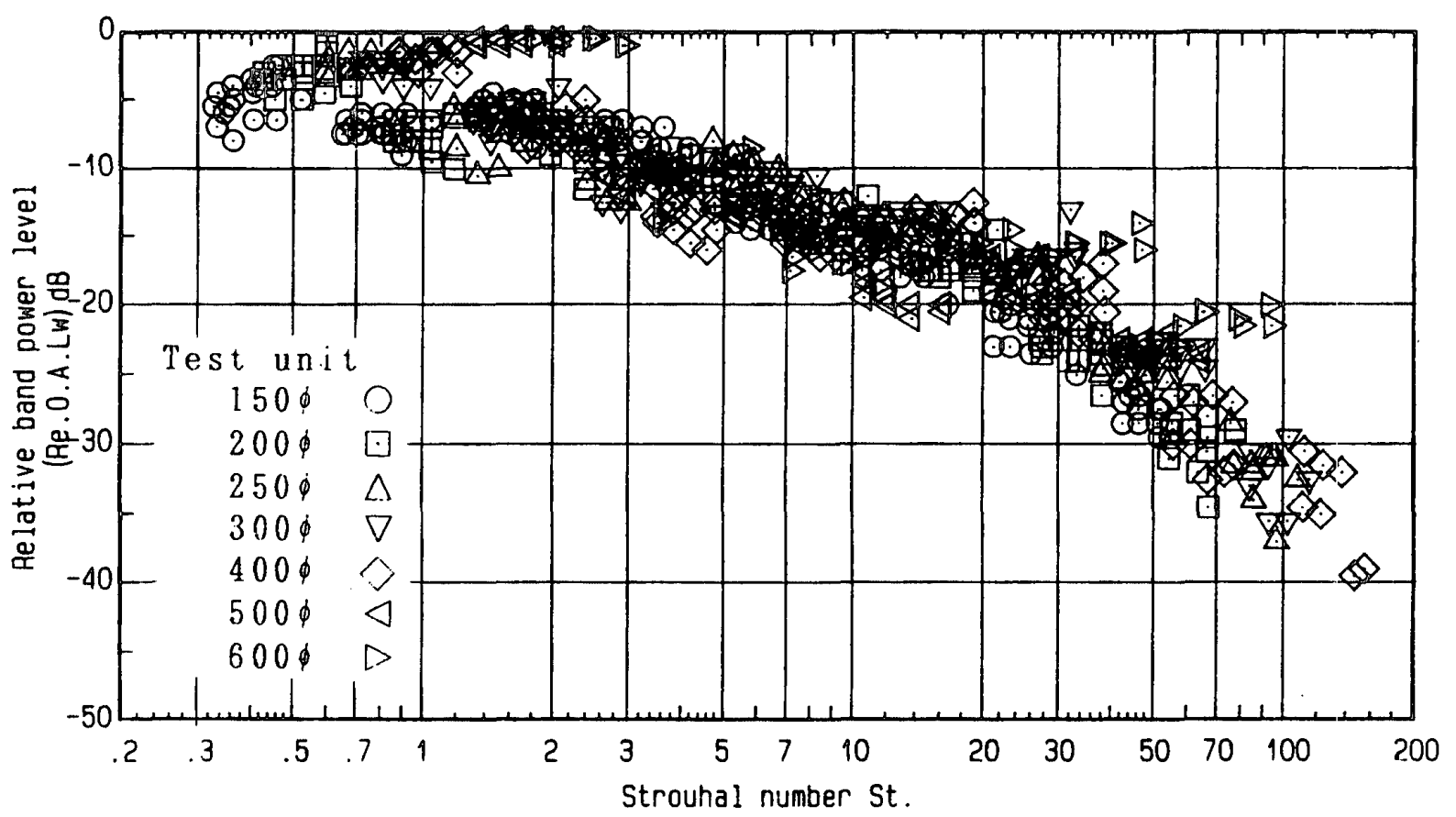

図一23 発生音の周波数特性（円形断面ダクト)

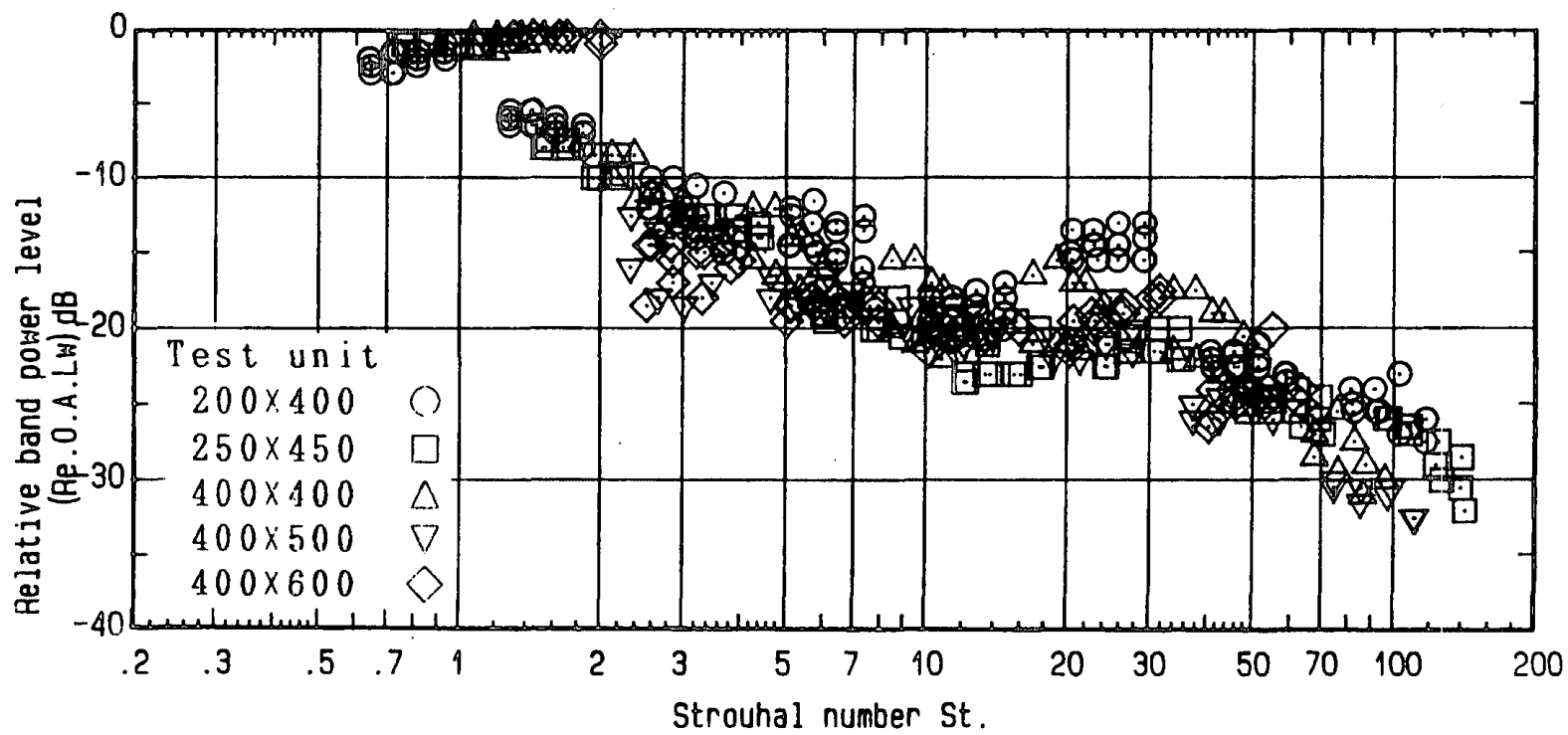

図一24 発生音の周波数特性 (長方形断面ダクト) 
さによる相違は，いずれもほとんどない。このことから， 今回の実験範囲内のグラス・ファイバ・ダクトでは，任 意の長さのダクト端におけるパワーレベル $L w_{m}$ と単位 長さ当たりの音響減衰を実験から求めて式（1）により 直管部発生音を求めることが可能であると考えられる。 直管部発生音才ーバーオール・パワーレベルを $0 \mathrm{~dB}$ としたときの相対バンド・パワーレベルとストロハル数 $N_{\text {str. }}\left(N_{\text {str }}=f \cdot D / V, f:\right.$ オターブ・バンド中心周波 数 $(\mathrm{Hz}), D$ : 直径あるいは等価直径 $(\mathrm{m}), V$ : 平均流 速 $(\mathrm{m} / \mathrm{s}))$ との関係を図一 23 および 24 に示す。円形お よび長方形断面いずれも供試体発生音の周波数特性は, 一部を除き，断面寸法によらず相対バンド・パワーレベ ルとストロハル数 $N_{\text {str. }}$ との関係で全体的に傾向がほぼ まとまっており，ストロハル数が大きくなれば，相対バ ンド・パワーレベルは小さくなる傾向がある。

\section{5. 結 論}

今回実験を行った供試体の特徴を以下にまとめる。

1) 摩擦抵抗係数入は, 円形および長方形断面いずれ も 0.024 前後を示す。

2). 円形断面は, 直径が大きくなるにつれて音響減衰は 小さくなる。長方形断面も寸法が大きくなるにつれて音 響減衰は小さくなるが，一部を除き，全体的に大きな差 はない。

また, 鉄板ダクト直後 $1 \mathrm{~m}$ までの円形および長方形断 面ダクトの音響诚衰は, 単位長さ当たりの音響诚衰より 全体的に大きいが，傾向としては，それらと同様に断面 寸法が大きくなるに従って減衰量は小さくなる。

3）直管部発生音のオーバーオール・パワーレベルは平 均流速のほぼ 6 乗に比例する。

4) 円形および長方形断面いずれも発生音の周波数特性
は，一部を除き，断面寸法によらず相対バンド・パワー レベルとストロハル数 $N_{\text {str. }}$ との関係で全体的に傾向が ほぼまとまっており，ストロハル数が大きくなれば，相 対バンド・パワーレベルは小さくなる傾向がある。

以上, 前回の測定方法により求めた気流特性, 音響娍 衰および側壁の遮音特性に加えて, 新たに, 気流による 発生音を測定し, 任意の長さのダクト端における発生音 パワーレベルの算出法を明らかにした。

\section{謝 辞}

本研究にあたり，グラスロン・ダクト K.K. の加藤 孝義氏に多大のご協力をいただいた。

また，本実験において，当時日大助手であった飯島和 俊氏（現日本ノイズ・コントロールK.K. ), 日本大学 の大学院生, 卒論生の諸君の労を多とした。ここに記し て深謝する。

\section{参考文献}

1) 板本守正, 塩川博義：グラス・ファイバ・ダクト直管部, 曲管部および分岐部の気流および音響特性について；日 本建築学会計画系論文報告集, No. 397, pp. 9 22, 1989.3

2) 渡辺 要, 勝田高司, 石井聖光, 後藤 滋, 寺沢達二, 板本守正：送風時におけるダクト系統の発生騒音に関す る研究; 空気謂和・衛生工学 第 37 巻, No. 5, pp. 22 $33,1963.5$

3）板本守正, 塩川博義ほか 1 名：グラス・ファイバ・ダク 卜直管部の気流および音響特性について;日本建築学会 大会学術講演梗概集, pp. 171 172, 1986.8

4）板本守正, 塩川博義：グラス・ファイバ・ダクト直管部 の気流および音響特性について;日本音響学会講演論文 集，pp. 537 538，1986. 10

（1991 年 4 月 10 日原稿受理，1991 年 8 月 9 日採用決定） 